\title{
PROGNOSTIC VALUE OF D-DIMER IN YOUNGER PATIENTS WITH PULMONARY EMBOLISM
}

Ljiljana Jovanović ${ }^{1}$, Vesna Subota ${ }^{1}$, Milena Rajković ${ }^{1}$, Bojana Subotić ${ }^{2}$, Boris Džudović ${ }^{2}$, Nataša Novčić2 Jovan Matijašević $^{3}$, Milica Mirić ${ }^{3}$, Sonja Šalinger ${ }^{4}$, Nataša Marković Nikolić ${ }^{5}$, Maja Nikolić ${ }^{6}$, Vladimir Miloradović ${ }^{2}$, Ljiljana Kos ${ }^{7}$, Tamara Kovačevic-Preradović ${ }^{7}$ and Slobodan Obradović $^{2,8}$ ${ }^{1}$ Institute of Biochemistry, Military Medical Academy, Belgrade, Serbia

${ }^{2}$ Clinic of Cardiology and Emergency Internal Medicine, Military Medical Academy, Belgrade, Serbia ${ }^{3}$ Institute for Pulmonary Diseases of Vojvodina, School of Medicine, University of Novi Sad, Sremska Kamenica, Serbia ${ }^{4}$ Clinic of Cardiology, Clinical Center Nis, University of Nis, Serbia

${ }^{5}$ University Clinical Center Zvezdara, School of Medicine, University of Belgrade, Serbia

${ }^{6}$ Clinic of Cardiology, Clinical Center Kragujevac, School of Medicine, University of Kragujevac, Serbia

${ }^{7}$ Clinic of Cardiology, Clinical Center Banja Luka, School of Medicine, University of Banja Luka, Bosnia and Herzegovina ${ }^{8}$ School of Medicine, University of Defense, Belgrade, Serbia

\section{PROGNOSTIČKA VREIDNOST D-DIMERA KOD MLADIH PACIJENATA SA PLUĆNOM TROMBOEMBOLIJOM}

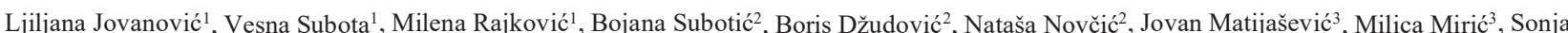
Šalinger ${ }^{4}$, Nataša Marković Nikolić ${ }^{5}$, Maja Nikolić ${ }^{6}$, Vladimir Miloradovićc ${ }^{6}$, Ljiljana Kos ${ }^{7}$, Tamara Kovačevic-Preradović ${ }^{7}$ i Slobodan Obradović2,8 ${ }^{1}$ Institut za biohemiju, Vojnomedicinska akademija, Beograd, Srbija

${ }^{2}$ Klinika za kardiologiju i hitne interne bolesti, Vojnomedicinska akademija, Beograd, Srbija

${ }^{3}$ Institut za plućne bolesti Vojvodine, Medicinski fakultet, Univerzitet u Novom Sadu, Sremska Kamenica, Srbija ${ }^{4}$ Klinika za kardiologiju, Klinički centar Niš, Univerzitet u Nišu, Srbija

${ }^{5}$ Univerzitetski klinički centar Zvezdara, Medicinski fakultet, Univerzitet u Beogradu, Srbija

${ }^{6}$ Klinika za kardiologiju, Klinički centar Kragujevac, Fakultet medicinskih nauka, Univerzitet u Kragujevcu, Srbija

Klinika za kardiologiju, Klinički centar Banja Luka, Medicinski fakultet, Univerzitet u Banja Luci, Bosna i Hercegovina ${ }^{8}$ Medicinski fakultet, Univerzitet odbrane, Beograd, Srbija

\section{ABSTRACT}

In patients with pulmonary embolism (PE), the D-Dimer assay is commonly utilized as part of the diagnostic workup, but data on D-Dimer for early risk stratification and short-term mortality prediction are limited. The purpose of this study was to determine D-Dimer levels as a predictive biomarker of PE outcomes in younger ( $<50$ years of age) compared to older patients. We conducted retrospective analysis for 930 patients diagnosed with PE between 2015 and 2019 as part of the Serbian University Multicenter Pulmonary Embolism Registry (SUPER).All patients had D-Dimer levels measured within 24 hours of hospital admission. The primary outcome was mortality at 30 days or during hospitalization. Patients were categorized into two groups based on age $(\leq 50$ and $>50$ years of age). Younger patients constituted $20.5 \%$ of the study cohort. Regarding all-cause mortality, 5.2\% (10/191) of patients died in group under the 50 years of age; the short-term all-causemortality was $12.4 \%$ (92/739) in older group.We have found that there was significant difference in plasma D-Dimer level between patients $\leq 50$ years of age and older group $(>50), p=0.006$. D-Dimer plasma level had good predictive value for the primary outcome in younger patients (c-statistics $0.710 ; 95 \%$ CI, 0.640-0.773; $p<0.031$ ). The optimal cutoff level for D-Dimer to predict PE-cause death in patients aged $>$ 50 years was found to be $8.8 \mathrm{mg} / \mathrm{l} \mathrm{FEU(c-statistics} \mathrm{0,580;95 \%}$ CI 0.544-0.616; $p=0.049$ ). In younger PE patients, D-Dimer levels have good prognostic performance for 30-day all-cause mortalityand concentrations above $6.3 \mathrm{mg} / \mathrm{l} \mathrm{FEU}$ are associated with increased risk of death. D-Dimer in patients aged over 50 years does not have predictive ability for all-caused short-term mortality. The relationship between D-Dimer and age in patients with $P E$ may need further evaluation.

Keywords: D-Dimer, pulmonary embolism, younger population, mortality

\section{SAŽETAK}

Određivanje D-Dimera je deo dijagnostičkog procesa kod pacijenata obolelih od plućne tromboembolije (PE), međutim ima malo podataka o upotrebi D-Dimera u predviđanju rizika $i$ kratkotrajnog mortaliteta, Cilj ove studije je utvrdivanje uloge D-Dimera kao prediktivnog biomarkera u proceni ishoda plućne tromboembolije kod mladih ( $<50$ godina) i starijih pacijenata. Retrospektivno je analizirano 930 pacijenata sa dijagnozom plućne tromboembolije u periodu od 2015 do 2019-te godine u okviru srpskog multicentričnog registra za plućnu tromboemboliju. DDimer je određivan svim pacijentima u prvih 24 sata od prijema u bolnicu. Praćena je smrtnost tokom hospitalizacije ili u prvih 30-dana od prijema. Pacijenti su na osnovu starosnog doba podeljeni u dve grupe (manje od 50 i više od 50 godina). Mlađi pacijenti sačinjavali su $20.5 \%$ studijske kohorte. Kod pacijenata mladih od pedest godina umrlo je 5.2\% (10/191), dok je kod starijih ukupna smrtnost bila 12.4\% (92/739). Pronađena je statistički značajna razlika vrednosti D-Dimera između pacijenata mladih od 50 godina $i$ starije grupe ispitanika (>50 godina), $p=0.006$. Vrednost D-Dimera u plazmi ima dobru prediktivnu vrednost za smrtnost kod mladih pacijenata (c-statistika 0.710; 95\% CI, 0.640-0.773; $p<0.031$ ). Utvrđen je odgovarajući cutoff za predvidanje smrtnosti direktno povezane sa PE kod pacijenata koji imaju vise od 50 godina i iznosi $8.8 \mathrm{mg} / \mathrm{l} \mathrm{FEU} \mathrm{(c-statistika}$ 0,580; 95\% CI 0.544-0.616; $p=0.049$ ). Kod mladih pacijenata $D$ dimer ima dobre prognosticke karakteristike u utvrdivanju 30-to dnevne smrtnosti, tako da su koncetracije D-Dimera iznad 6.3 mg/l FEU povezane sa povećanim mortalitetom. D-Dimer kod pacijenata starijih od 50 godina nema ulogu u predviđanju kratkotrajne smrtnosti. Potrebna su dalja istraživanja kako bi se proučio odnos između vrednosti D-Dimera i starosne dobi kod pacijenata sa plućnom tromboembolijom.

Ključne reči: D-Dimer, plućna tromboembolija, mlađa populacija, smrtnost. 


\section{INTRODUCTION}

Pulmonary embolism (PE) is a common life-threatening condition which contributes to the global burden of cardiovascular diseases in terms of morbidity and mortality(1-5). The 30-day mortality rate due to PE exceeds $15 \%$ (6). Prompt diagnosis, risk assessment and adequate treatment can improve the outcome (7). A reliable risk stratification of PE severity based on the 2019 ESC Guidelines, pulmonary embolism severity index (PESI) or simplified PESI (sPESI) indicates risk of early (inhospital or 30-day) death(8-11). Adding biomarkers data may help in improving prognosis and categorization of patients with acute PE into risk classes (11-12). The use of elevated D-Dimer levels to evaluate severity of PE remains limited (6). D-Dimer age adapted cutoff level (DDimer cut off $=$ age $\times 10 \mu \mathrm{g} / \mathrm{l} \mathrm{FEU}$,age $>50)$ defined categories of patients $\leq 50$ and $>50$ years of age $(13,14)$. Although it is well recognized that $\mathrm{PE}$ has been shown to be major cause of mortality in younger population, there are relatively few studies looking particularly at PE in this age group (15).The aim of this study is to determine age-specifically role of D-Dimer in both age groups in patients with PE.

\section{MATERIALS AND METHODS}

The present report is a retrospective analysis of the Serbian University Multicenter Pulmonary Embolism Registry (SUPER). The PE patients diagnosed by multidetector computed pulmonary angiography (MDCT-PA) in university cardiology or pulmonology clinics (Military Medical Academy Belgrade, Institute for Pulmonary Diseases of Vojvodina Sremska Kamenica, Clinical Center Nis, University Clinic Zvezdara and Clinical Center Kragujevac) from January 2015 to September 2019, were selected. The study end point was defined asthirty-day mortality in patients who died within 30 days of hospital admission. In 930 patients who were aged $\geq 18$ years, D-Dimer tests were performed within 24 hours of hospitalization as a part of diagnostic workup. TheD-Dimer levels in citrated plasma were measured via Siemens (Marburg, Germany) BCS analyzer and the immunoturbidimetric assay (Siemens Innovance D-Dimer test kit). Patients were categorized into two groups based on age $(\leq 50$, $>50$ years).

\section{STATISTICAL ANALYSIS}

Descriptive statistics are presented as frequency and percentages for categorical data and their distribution was further analyzed with $\chi^{2}$ test. D-Dimer was given as median and $25^{\text {th }}-75^{\text {th }}$ percentile. Comparison in D-Dimer between two independent groups was analyzed with Mann-Whitney test. All tests were performed using SPSS 21.0 (SPSS Inc., Chicago, IL, USA) and $p$ values of $<0.05$ were considered significant. Receiver operating curve (ROC) analysis was utilized to determine area under the curve (AUC) and cutoff level for DDimer in both age groups using MedCalc for Windows version 18.11.3 (MedCalc Software, Acacialaan, Belgium).

\section{RESULTS}

The final analysis enrolled 930 patients with PE, mean age $62.96 \pm 15.46$ and significant difference between deceased patients $(69.44 \pm 14.74)$ and survivors $(62.16 \pm$ 15.37), $\mathrm{p}<0.001$. There were 102 short-term (within 30days)all-causedeaths of which $60.78 \%$ caused by PE.

Table 1. shows the baseline characteristics of the studied patients. Among the patients aged $>50$ years,BMI higher than $25(\mathrm{p}=0.032)$, chronic diseases such as diabetes mellitus ( $\mathrm{p}=0.043)$ and coronary heart failure $(\mathrm{p}=0.015)$, history of stroke $(\mathrm{p}=0.001)$ and thrombosis $(\mathrm{p}=0.028)$, were the major factors that would cause death. Beside kidney failure as the independent predictor of all-cause mortality for all PE patients $(\mathrm{p}<0.001)$, malignancy $(\mathrm{p}=0.018)$ was the most common risk factor in younger patients (age $\leq 50$ years). Younger patients may often have investigation for possible thrombophilia and pregnancy. Of the 36 patients who underwent a thrombophilia screen, 20 of them were positive and 3 patients were pregnant.

There was significant difference in plasma D-Dimer level between patients $\leq 50$ years of age and older group $(>50)$, $p=$ 0.006 . D-Dimer concentration below group specific cutoff were in $1.6 \%$ of patients age $\leq 50$ years (cut off $=0.5 \mathrm{mg} / \mathrm{l}$ FEU) and $2.7 \%$ of older population (cut off $=$ age $\times 0.01 \mathrm{mg} / 1$ FEU). D-Dimer values between deceased and survivors was significantly different in patients aged $\leq 50$ years $(\mathrm{p}=0.026)$. In older groupno significant difference was observed with respect to all-cause mortality, but mean D-Dimer level was significantly higher in patients who died of acute PEwithin 30days than survivors $(\mathrm{p}=0.005)$.

Among patients classified as being at low risk by the sPESI, mortality was $2.7 \%(9 / 330)$. The sPESI classified 600 patients $(64.5 \%)$ in the high risk group $(\geq 1$ point $)$ and mortality of high risk patients was $15.5 \%$ (93/600) (Table 2). sPESI and PESI score stratified patients as it was presumed, and 30-day mortality rate were higher in patients with sPESI $\geq 1$ and increased significantly from the first to the fifth PESI risk class in both age groups. The median D-Dimer level in the sPESI $\geq 1$ group was significantly higher than in the sPESI= 0 group, $5.0 \mathrm{mg} / \mathrm{l} \mathrm{FEU} \mathrm{(2.6-9.5} \mathrm{mg/l} \mathrm{FEU)} \mathrm{versus} 4.4$ $\mathrm{mg} / 1 \mathrm{FEU}(2.3-8.0 \mathrm{mg} / \mathrm{l} \mathrm{FEU})$, respectively, $\mathrm{p}=0.029$, as shown in Figure 1. According to sPESI criteria in patients $\leq$ 50 years of age, high-risk patients had significantly higher DDimer levels than low-risk group $(4.7 \mathrm{mg} / \mathrm{l} \mathrm{FEU}, 3.6 \mathrm{mg} / 1$ FEU, $\mathrm{p}=0.005)$. On the other hand,PESIclassificationin patients aged over 50 years showed slightly significant difference between five risk groups $(\mathrm{p}=0.05)$.

PE patients were evaluated according to the algorithm proposed by the 2019 ESC guidelines for prediction risk of early mortality. The mortality was $2.2 \%(7 / 319)$ in the low risk class, $5.3 \%(11 / 206)$ in the intermediate-low, $14.8 \%$ $(41 / 277)$ in the intermediate-high and 33.6\% (43/128) in the high risk class. 
To estimate the predictive capability of the D-Dimer in different age groups ( $\leq 50 \mathrm{vs}>50)$, a ROC analysis was conducted (Table 3). D-Dimer concentrations above $6.3 \mathrm{mg} / 1$ FEU was good prognostic biomarker for 30-day all-cause mortality in younger patients (c-statistics 0.710 ; 95\% CI, $0.640-0.773 ; \mathrm{p}=0.031$ ). In population over 50 years of age, D-Dimer showed modest discriminative power for 30-day PE-cause mortality with $8.8 \mathrm{mg} / \mathrm{l} \mathrm{FEU}$ cutoff and an c-statistics 0,$580 ; 95 \%$ CI $0.544-0.616 ; p=0.049$.

\section{DISCUSSION}

D-Dimer levels are used in diagnostic workup of suspected $\mathrm{PE}$, and its elevated values are predictive in detecting and recurrence of PE (16-18). There was a relationship between increased D-Dimer concentrations and clot burden, thrombus localization, major bleeding and RV dysfunction (18-20). Studies of D-Dimer in patients with PE have demonstrated various data regarding the severity of PE and early risk stratification (22-23).

In this study, high risk patients stratified according to newrevised ESC Guidelines were $18.4 \%$ of all PE patients and up to one third of them died within the first 30-days. Since risk of development of PE doubles with each decade after forties (24), 90.7\% of deceased in high risk group were older than 50 years.But, D-Dimer levels were not significantly associated with short-term all-cause mortality in older patients. The reason might be as followings: D-Dimer as a fibrin degradation product can be increased in cancer, infections and wide spectrum of inflammatory, vascular and systemic diseases. Also, comorbidities increase with age and may affect the outcome.
Thus comorbidity burden may explain some of limitations of D-Dimer prognostic performance (25-26). Consequently, D-Dimer was slightly significant predictor of PEcause mortality.

Prognostic ability of D-Dimer to predict short-term mortality in younger population with PE was observed. Our data showed that every fifth patient with PE was under 50 years of age, similar to theother findings (27-28). In this study was found a difference for the AUCs of D-Dimer in patients $<50$ and $\geq 50$ years of age, showing much better discrimination in the younger group (AUC of 0.710 vs. 0.541, respectively). There were no deaths in patients $(<50$ years of age) with $\mathrm{SPESI}=0$ and in higher risk classes of PESI ( 4 th and $5^{\text {th }}$ ). It appears that lower mortality, better general health status and lower comorbidity rate in younger patients (27) were reflected by behavior of D-Dimer.

The main limitation of this study is the relatively low number of deaths in younger population and its retrospective nature. Moreover, D-Dimer values below age-adjusted cutoff were present in $2.5 \%$ of patients. These results were considered as false negative because of increased age of thrombus, collagenized poorly degradable fibrin and prior treatment with anticoagulation (29).

In conclusion, our findings suggest that high levels of DDimer (6.3 mg/l FEU), measured on hospital admission, identify patients under 50 years of age at increased risk of death during the first 30-days of PE diagnosis. The use of DDimer in patients aged over 50 years does not have prognostic power for all-cause short-term mortality.

Table 1. Baseline characteristic between PE subgroups

\begin{tabular}{|c|c|c|c|c|c|c|c|c|c|c|}
\hline \multirow{3}{*}{\multicolumn{2}{|c|}{ Variables }} & \multicolumn{3}{|c|}{ All patients } & \multicolumn{3}{|c|}{$\leq 50$ years } & \multicolumn{3}{|c|}{$>50$ years } \\
\hline & & \multicolumn{9}{|c|}{ 30-day mortality } \\
\hline & & $\begin{array}{c}\mathrm{No} \\
\mathrm{N}=828\end{array}$ & $\begin{array}{c}\text { Yes } \\
\mathrm{N}=102\end{array}$ & $\begin{array}{c}\mathrm{p} \\
\text { value }\end{array}$ & $\begin{array}{c}\text { No } \\
N=181\end{array}$ & $\begin{array}{c}\text { Yes } \\
\mathrm{N}=10\end{array}$ & $\begin{array}{c}\mathrm{p} \\
\text { value }\end{array}$ & $\begin{array}{c}\text { No } \\
\mathrm{N}=647\end{array}$ & $\begin{array}{c}\text { Yes } \\
\mathrm{N}=92\end{array}$ & $\begin{array}{c}\mathrm{p} \\
\text { value }\end{array}$ \\
\hline \multirow{2}{*}{$\begin{array}{c}\text { Gender, } \mathrm{N} \\
(\%)\end{array}$} & Male & $\begin{array}{c}408 \\
(49.3) \\
\end{array}$ & $\begin{array}{c}43 \\
(42.2) \\
\end{array}$ & \multirow{2}{*}{0.208} & $\begin{array}{c}114 \\
(63.0) \\
\end{array}$ & $\begin{array}{c}7 \\
(70.0) \\
\end{array}$ & \multirow{2}{*}{0.749} & $\begin{array}{c}294 \\
(45.4)\end{array}$ & $\begin{array}{c}36 \\
(39.1) \\
\end{array}$ & \multirow{2}{*}{0.265} \\
\hline & $\begin{array}{l}\mathrm{Fe}- \\
\text { male }\end{array}$ & $\begin{array}{l}420 \\
(50.7)\end{array}$ & $\begin{array}{c}59 \\
(57.8) \\
\end{array}$ & & $67(37.0)$ & $\begin{array}{c}3 \\
(30.0) \\
\end{array}$ & & $\begin{array}{c}353 \\
(54.6) \\
\end{array}$ & $\begin{array}{c}56 \\
(60.9)\end{array}$ & \\
\hline \multicolumn{11}{|c|}{ Comorbidities (N, \%) } \\
\hline \multicolumn{2}{|c|}{ Smoking } & $\begin{array}{c}141 \\
(18.2)\end{array}$ & $\begin{array}{c}11 \\
(12.1)\end{array}$ & 0.078 & $60(34.9)$ & $\begin{array}{c}1 \\
(11.1)\end{array}$ & 0.215 & $81(13.5)$ & $\begin{array}{c}10 \\
(12.2)\end{array}$ & 0.273 \\
\hline \multicolumn{2}{|c|}{ Oral contraceptives } & $12(1.5)$ & $0(0)$ & 0.625 & $6(3.4)$ & $0(0)$ & 1.000 & $6(1)$ & $0(0)$ & 1.000 \\
\hline \multicolumn{2}{|c|}{$\begin{array}{c}\text { BMI 25-29.99, Over- } \\
\text { weight }\end{array}$} & $\begin{array}{c}247 \\
(35.8)\end{array}$ & $\begin{array}{c}20 \\
(24.4)\end{array}$ & \multirow{2}{*}{0.032} & $44(28.0)$ & $\begin{array}{c}2 \\
(22.2)\end{array}$ & \multirow{2}{*}{0.462} & $\begin{array}{c}203 \\
(38.2)\end{array}$ & $\begin{array}{c}18 \\
(24.7)\end{array}$ & \multirow{2}{*}{0.032} \\
\hline \multicolumn{2}{|c|}{$\mathrm{BMI} \geq 30$, Obese } & $\begin{array}{c}165 \\
(23.9) \\
\end{array}$ & $\begin{array}{c}17 \\
(20.7) \\
\end{array}$ & & $40(25.5)$ & $\begin{array}{c}1 \\
(11.1) \\
\end{array}$ & & $\begin{array}{c}125 \\
(23.5) \\
\end{array}$ & $\begin{array}{c}16 \\
(21.9) \\
\end{array}$ & \\
\hline \multicolumn{2}{|c|}{ COPD } & $89(10.7)$ & $\begin{array}{c}17 \\
(16.7)\end{array}$ & 0.097 & $5(2.8)$ & $0(0.0)$ & 1.000 & $84(13.0)$ & $\begin{array}{c}17 \\
(18.5)\end{array}$ & 0.148 \\
\hline \multicolumn{2}{|c|}{$\mathrm{CHF}$} & $\begin{array}{c}102 \\
(12.3)\end{array}$ & $\begin{array}{c}24 \\
(23.5)\end{array}$ & 0.003 & $7(3.9)$ & $\begin{array}{c}1 \\
(10.0)\end{array}$ & 0.355 & $95(14.7)$ & $\begin{array}{c}23 \\
(25.0)\end{array}$ & 0.015 \\
\hline
\end{tabular}




\begin{tabular}{|c|c|c|c|c|c|c|c|c|c|}
\hline CAD & $90(10.9)$ & $\begin{array}{c}19 \\
(19.0)\end{array}$ & 0.056 & $1(0.6)$ & $0(0.0)$ & 0.948 & $89(13.8)$ & $\begin{array}{c}19 \\
(21.1)\end{array}$ & 0.079 \\
\hline History of DVT/PE & $\begin{array}{c}119 \\
(14.5)\end{array}$ & $5(5.0)$ & 0.005 & $30(16.7)$ & $0(0.0)$ & 0.368 & $89(13.9)$ & $5(5.5)$ & 0.028 \\
\hline Hypertension & $\begin{array}{c}473 \\
(57.3)\end{array}$ & $\begin{array}{c}62 \\
(60.8)\end{array}$ & 0.525 & $29(16.0)$ & $\begin{array}{c}1 \\
(10.0)\end{array}$ & 1.000 & $\begin{array}{c}444 \\
(68.8)\end{array}$ & $\begin{array}{c}61 \\
(66.3)\end{array}$ & 0.632 \\
\hline MI+Stroke+ PAD & $\begin{array}{c}127 \\
(15.4)\end{array}$ & $\begin{array}{c}23 \\
(23.0)\end{array}$ & 0.061 & $9(5.0)$ & $0(0.0)$ & 1.000 & $\begin{array}{c}118 \\
(18.3)\end{array}$ & $\begin{array}{c}23 \\
(25.6)\end{array}$ & $<0.115$ \\
\hline DM & $\begin{array}{c}147 \\
(17.8)\end{array}$ & $\begin{array}{c}28 \\
(27.5)\end{array}$ & 0.022 & $13(7.2)$ & $0(0.0)$ & 1.000 & $\begin{array}{c}134 \\
(20.7)\end{array}$ & $\begin{array}{c}28 \\
(30.4)\end{array}$ & 0.043 \\
\hline History of stroke & $49(5.9)$ & $\begin{array}{c}17 \\
(16.7)\end{array}$ & $<0.001$ & $5(2.8)$ & $0(0.0)$ & 1.000 & $44(6.8)$ & $\begin{array}{c}17 \\
(18.5)\end{array}$ & 0.001 \\
\hline Malignancy & $98(11.8)$ & $\begin{array}{c}21 \\
(20.6)\end{array}$ & 0.018 & $10(5.5)$ & $\begin{array}{c}4 \\
(40.0)\end{array}$ & 0.003 & $88(13.6)$ & $\begin{array}{c}17 \\
(18.5)\end{array}$ & 0.205 \\
\hline Major surgery & $\begin{array}{c}126 \\
(15.2)\end{array}$ & $\begin{array}{c}15 \\
(14.7)\end{array}$ & 1.000 & $23(12.7)$ & $\begin{array}{c}2 \\
(20.0)\end{array}$ & 0.623 & $\begin{array}{c}103 \\
(15.9)\end{array}$ & $\begin{array}{c}13 \\
(14.1)\end{array}$ & 0.760 \\
\hline $\begin{array}{c}\text { Creatinine Clearance } \\
<60\end{array}$ & $\begin{array}{c}223 \\
(27.9)\end{array}$ & $\begin{array}{c}71 \\
(70.3)\end{array}$ & $<0.001$ & $8(4.6)$ & $\begin{array}{c}6 \\
(60.0)\end{array}$ & $<0.001$ & $\begin{array}{c}215 \\
(34.3)\end{array}$ & $\begin{array}{c}65 \\
(71.4)\end{array}$ & $<0.001$ \\
\hline $\begin{array}{c}\text { Creatinine Clearance } \\
<30\end{array}$ & $\begin{array}{c}45(5.7) \\
(28.7)\end{array}$ & $<0,001$ & $1(0.6)$ & $\begin{array}{c}3 \\
(30.0)\end{array}$ & $<0.001$ & $44(7.1)$ & $\begin{array}{c}26 \\
(28.6)\end{array}$ & $<0.001$ \\
\hline
\end{tabular}

Baseline characteristic between PE subgroups. ${ }^{*}$ p value $<$ 0.05 significant; (\%)- percentage of PE patients with (Yes) or without (No) adverse events.Abbreviations: M, male; F, female; BMI, body mass index; COPD, chronic obstructive pulmonary disease; CHF, coronary heart failure; DVT, deep vein thrombosis; $\mathrm{PE}$, pulmonary embolism; $\mathrm{CAD}$, coronary artery disease; MI, myocardial infarction; PAD, pulmonary artery disease; DM, diabetes mellitus;Data were missing for smoking $(7.1 \%)$, BMI $(17.1 \%)$, oral contraceptives $(3,4 \%)$, CAD $(0.3 \%), \quad$ DVT/PE $(0.8 \%)$, hypertension $(0.2 \%)$, MI+Stroke+PAD $(0.4 \%)$, history of stroke $(0.1 \%)$, creatinine clearance $<60(3.1 \%)$, creatinine clearance $<30(3.8 \%)$.

Table 2. Risk assessment in PE subgroups

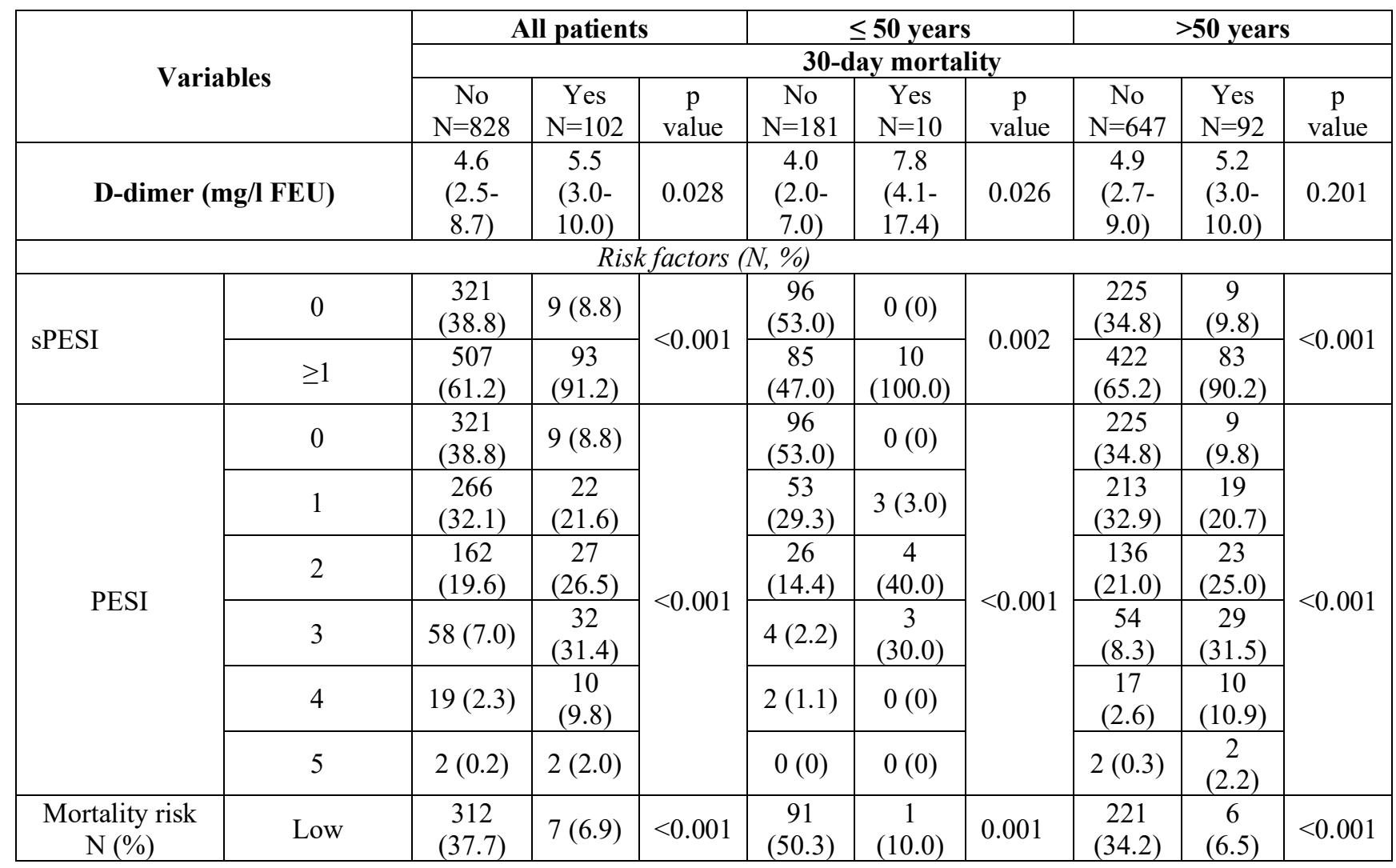




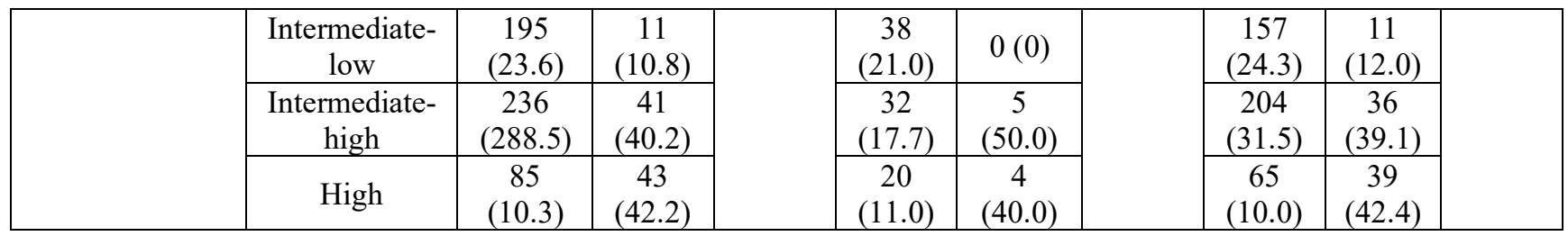

Data for D-Dimer are presented as a median, $25^{\text {th }}-75^{\text {th }}$ percentile. Baseline characteristic between PE subgroups.*p value $<0.05$ significant; (\%) - percentage of PE patients with
(Yes) or without (No) adverse events.Abbreviations: M, male; F, female; PE, pulmonary embolism; sPESI, simplified pulmonary embolism severity index.

Table 3. ROC Analysis for D-Dimer predicting adverse outcomes in PE subgroups

\begin{tabular}{|l|c|c|c|c|c|c|c|}
\hline & $\mathrm{N}$ & $\mathrm{AUC}$ & $95 \% \mathrm{CI}$ & $\mathrm{p}$ & Cut-off & Sensitivity & Specificity \\
\hline All patients & 930 & 0.567 & $0.534-0.599$ & 0.031 & 7.6 & 41.18 & 70.89 \\
\hline <50 years & 191 & 0.710 & $0.640-0.773$ & 0.031 & 6.3 & 70.00 & 72.93 \\
\hline > 50 years & 739 & 0.541 & $0.504-0.578$ & 0.212 & 8.8 & 35.87 & 74.19 \\
\hline
\end{tabular}

AUC indicates area under the curve.

Figure 1. Median D-Dimer levels (mg/l FEU) in $\mathrm{sPESI}=0$ and $\mathrm{sPESI} \geq 1 \quad(\mathrm{sPESI}>0)$ patients

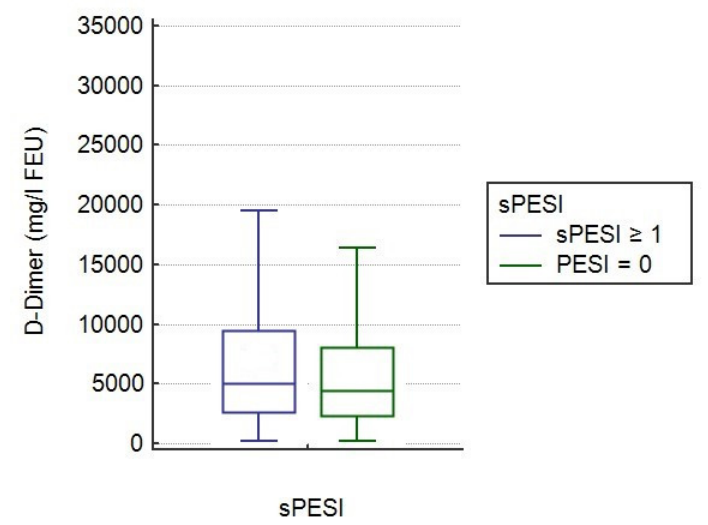

Data reported as median values, interquartile ranges (boxes), and 2.5th and 97.5th percentiles (whiskers).

\section{REFERENCES}

1. Rivera-Lebron B, McDaniel M, Ahrar K, Alrifai A, Dudzinski DM, Fanola C, Blais D, Janicke D, Melamed R, Mohrien K, Rozycki E. Diagnosis, treatment and follow up of acute pulmonary embolism: consensus practice from the PERT consortium. Clinical and Applied Thrombosis/Hemostasis. 2019 Jun 10;25:107602961985 3037.

2. Akhter M, Kline J, Bhattarai B, Courtney M, Kabrhel C. Ruling out pulmonary embolism in patients with high pretest probability. Western Journal of Emergency Medicine. 2018 May; 19(3):487.

3. Yamamoto T. Management of patients with high-risk pulmonary embolism: a narrative review. Journal of intensive care. 2018 Dec;6(1):16.

4. Takahashi J, Shiga T, Fukuyama Y, Hoshina Y, Homma Y, Mizobe M, Numata K, Inoue T, Funakoshi H. New
D-dimer threshold for Japanese patients with suspected pulmonary embolism: a retrospective cohort study. International journal of emergency medicine. 2019 Dec $1 ; 12(1): 23$.

5. Pernod G, Caterino J, Maignan M, Tissier C, Kassis J, Lazarchick J, DIET Study Group. D-dimer use and pulmonary embolism diagnosis in emergency units: why is there such a difference in pulmonary embolism prevalence between the United States of America and countries outside USA?.PLoS One. 2017;12(1).

6. Jia D, Liu F, Zhang Q, Zeng GQ, Li XL, Hou G. Rapid on-site evaluation of routine biochemical parameters to predict right ventricular dysfunction in and the prognosis of patients with acute pulmonary embolism upon admission to the emergency room. Journal of clinical laboratory analysis. 2018 May;32(4):e22362. 
7. Liu X, Chang S, Fu C, Huo Z, Zhou J, Liu C, Li S, Sun A. Predictors of mid-term prognosis and adverse factors in acute pulmonary embolism. Therapeutic advances in respiratory disease. 2017 Aug;11(8):293-300.

8. Simon LE, Iskin HR, Vemula R, Huang J, Rauchwerger AS, Reed ME, Ballard DW, Vinson DR. Emergency Department Patient Satisfaction with Treatment of Lowrisk Pulmonary Embolism. Western Journal of Emergency Medicine. 2018 Nov;19(6):938.

9. Porres-Aguilar M, Anaya-Ayala JE, Heresi GA, RiveraLebron BN. Pulmonary embolism response teams: a novel approach for the care of complex patients with pulmonary embolism. Clinical and Applied Thrombosis/Hemostasis. 2018 Dec;24(9_suppl):48S-55S.

10. Barco S, Mahmoudpour SH, Planquette B, Sanchez O, Konstantinides SV, Meyer G. Prognostic value of right ventricular dysfunction or elevated cardiac biomarkers in patients with low-risk pulmonary embolism: a systematic review and meta-analysis. European heart journal. 2019 Mar 14;40(11):902-10.

11. Lee JH, Huh JW, Hong SB, Oh YM, Shim TS, Lim CM, Lee SD, Koh Y, Kim WS, Lee JS. Prognostic value of blood biomarkers in patients with unprovoked acute pulmonary embolism. Annals of Thoracic Medicine. 2019 Oct;14(4):248.

12. Becattini C, Agnelli G. Risk stratification and management of acute pulmonary embolism. Hematology 2014, the American Society of Hematology Education Program Book. 2016 Dec 2;2016(1):404-12.

13. Li J, Zhang F, Liang C, Ye Z, Chen S, Cheng J. The Diagnostic Efficacy of Age-Adjusted D-Dimer Cutoff Value and Pretest Probability Scores for Deep Venous Thrombosis. Clinical and Applied Thrombosis/Hemostasis. 2019 Feb 11;25:1076029619826317.

14. Konstantinides SV, Meyer G, Becattini C, Bueno H, Geersing GJ, Harjola VP, Huisman MV, Humbert M, Jennings CS, Jiménez D, Kucher N. 2019 ESC Guidelines for the diagnosis and management of acute pulmonary embolism developed in collaboration with the European Respiratory Society (ERS) The Task Force for the diagnosis and management of acute pulmonary embolism of the European Society of Cardiology (ESC). European heart journal. 2020 Jan 21;41(4):543-603.

15. Hewitt M, Devine C, Gonzalez L. Pulmonary embolism in young adults (18-45 years). European journal of internal medicine. 2018 Aug 1;54:e23-4.

16. Geissenberger F, Schwarz F, Probst M, Haberl S, Gruetzner S, Kroencke T, von Scheidt W, Berghaus TM. D-Dimer Predicts Disease Severity but Not Long-Term Prognosis in Acute Pulmonary Embolism. Clinical and Applied Thrombosis/Hemostasis. 2019 Jul 12;25:1076029619863495.

17. Kupis RW, Goldman-Mazur S, Polak M, Ząbczyk M, Undas A. Faster fibrin clot degradation characterizes patients with central pulmonary embolism at a low risk of recurrent peripheral embolism. Scientific reports. 2019 Jan 11;9(1):1-8.
18. Gong X, Duan Z, Yuan Y. Long-term prognosis and related factors towards patients with acute pulmonary thromboembolism. International journal of clinical and experimental medicine. 2015;8(5):7906.

19. Johnsen HS, Hindberg K, Bjøri E, Brodin EE, Brækkan SK, Morelli VM, Hansen JB. D-Dimer Measured at Diagnosis of Venous Thromboembolism is Associated with Risk of Major Bleeding. TH Open. 2019 Jan;3(01):e77-84.

20. El-Menyar A, Asim M, Nabir S, Ahmed MN, Al-Thani H. Implications of elevated cardiac troponin in patients presenting with acute pulmonary embolism: an observational study. Journal of Thoracic Disease. 2019 Aug;11(8):3302.

21. Sunnetcioglu A, Sertogullarindan B, Ozbay B, Asker S, Ekin S. Assessments of the associations of thrombus localization with accompanying disorders, risk factors, Ddimer levels, and the red cell distribution width in pulmonary embolism. Clinics. 2015 Jun;70(6):441-5.

22. Kozlowska M, Plywaczewska M, Koc M, Pacho S, Wyzgal A, Zdonczyk O, Furdyna A, Ciurzynski M, Kurnicka K, Jankowski K, Lipinska A. D-Dimer assessment improves the Simplified Pulmonary Embolism Severity Index for in-hospital risk stratification in acute pulmonary embolism. Clinical and Applied Thrombosis/Hemostasis. 2018 Nov;24(8):1340-6.

23. Sikora-Skrabaka M, Skrabaka D, Ruggeri P, Caramori G, Skoczyński S, Barczyk A. D-dimer value in the diagnosis of pulmonary embolism - may it exclude only? Journal of thoracic disease. 2019 Mar;11(3):664.

24. Barco S, Konstantinides SV. Pulmonary embolism: Contemporary medical management and future perspectives. Annals of vascular diseases. 2018 Aug 3:ra-18.

25. Friz HP, Pezzetti V, Orenti A, Caleffi A, Corno V, Crivellari C, Petri F, Friz MP, Punzi V, Teruzzi D, d'Oro LC. Comorbidity burden conditions the prognostic performance of D-dimer in elderly patients with acute pulmonary embolism. The American journal of emergency medicine. 2019 May 1;37(5):799-804.

26. Barth BE, Waligora G, Gaddis GM. Rapid systematic review: age-adjusted D-Dimer for ruling out pulmonary embolism. The Journal of emergency medicine. 2018 Oct 1;55(4):586-92.

27. Kiluk IE, Krajewska A, Kosacka U, Tycińska A, Milewski R, Musiał W, Sobkowicz B. Different manifestations of pulmonary embolism in younger compared to older patients: Clinical presentation, prediction rules and long-term outcomes. Advances in medical sciences. 2017 Sep 1;62(2):254-8.

28. Kröger K, Moerchel C, Moysidis T, Santosa F. Incidence rate of pulmonary embolism in Germany: data from the federal statistical office. Journal of thrombosis and thrombolysis. 2010 Apr 1;29(3):349-53.

29. Francis S, Limkakeng A, Zheng H, Hollander J, Fermann G, Parry BA, Lovecchio F, Werner N, Schellong S, Kabrhel C. Highly Elevated Quantitative D-Dimer Assay Values Increase the Likelihood of Venous Thromboembolism. TH Open. 2019 Jan;3(01):e2-9. 